\title{
Deteksi porfirin besi pada pakan darah nyamuk liar antropofilik menggunakan uji benzidine
}

\author{
${ }^{1}$ Stevano Mengko \\ ${ }^{2}$ Josef S. B. Tuda \\ ${ }^{1}$ Kandidat Skripsi Fakultas Kedokteran Universitas Sam Ratulangi Manado
${ }^{2}$ Bagian Parasitologi Klinik Fakultas Kedokteran Universitas Sam Ratulangi Manado
Email: stevano.mengko@gmail.com
}

Abstract: The existence of human blood in mosquito's bloodmeal is the characteristic of mosquitoes that bite humans (anthrophophilic). Anthropophilic is one of the indicator to determine the vectorial competence to assess effective and efficient vector. The anthropophilic characteristic was measured by detection of human blood using precipitin test. Benzidine test can be used to detection iron porphyrin through oxidation reaction and catalyzed by hemoglobin as peroxidase enzyme. Heme detection of mosquitoe's bloodmeal using benzidine in Indonesia has not been reported yet. This study was aimed to obtain the effectiveness of benzidine test to detection human blood in antrophophilic mosquito's bloodmeal. The mosquitoes were collected using human bait and sweeping collection technique at morning (06:00-09:00), afternoon (15:00-18:00), and in the night (20:00-00:00), and then determine by benzidine test. The results showed that from the collected mosquitoes there were 158 female mosquitoes of Aedes spp and Culex spp. The benzidine test showed 155 female mosquitoes showed discoloration on the indicator and 3 female mosquitoes did not. Conclusion: Benzidine test was effective to detection human blood from the mosquito's bloodmeal to determine anthrophophilic mosquitoes.

Keywords: anthropophilic, bloodmeal, benzidine.

\begin{abstract}
Abstrak: Adanya darah manusia dalam pakan darah nyamuk merupakan ciri dari nyamuk yang memiliki kesukaan menggigit hospes manusia (antropofilik). Sifat antropofilik nyamuk adalah salah satu indikator dalam penilaian kompetensi vektorial untuk menilai vektor yang efektif dan efisien. Penilaian sifat antropofilik dilakukan melalui penilaian pakan darah dengan uji presipitasi. Tes benzidine adalah salah satu uji yang dapat dilakukan karena efektif dalam mendeteksi porfirin besi (heme) melalui reaksi oksidasi yang dikatalisis oleh heme sebagai enzim peroksidase. Deteksi porfitin besi pada pakan darah nyamuk menggunakan benzidine belum banyak dilaporkan di Indonesia. Tujuan penelitian ini yaitu untuk mengetahui apakah nyamuk yang mengisap darah hospes manusia (antropofilik) dapat dideteksi dengan uji benzidine. Penelitian dilakukan dengan menangkap nyamuk betina menggunakan umpan manusia dan sweeping pada jam puncak menggigit nyamuk yaitu pagi (06:00-09:00), sore (15:00-18:00), dan malam (20:00-00:00) lalu dilakukan tes benzidine. Hasil: Pada penangkapan nyamuk ditemukan 158 ekor nyamuk betina yang terdiri dari genus Aedes spp dan Culex spp. Pada uji presipitasi ditemukan 155 ekor nyamuk mengalami perubahan warna yang bervariasi pada indikator dan 3 ekor nyamuk tidak berubah warna. Simpulan: uji benzidine dapat dilakukan untuk penilaian sumber pakan darah nyamuk dalam menentukan sifat antropofilik nyamuk.
\end{abstract}

Kata kunci: antropofilik, pakan darah, benzidine. 
Di Indonesia penyakit menular yang ditularkan oleh vektor masih merupakan masalah kesehatan yang penting, salah satunya ialah peranan vektor nyamuk. Genus nyamuk yang menularkan beberapa penyakit antara lain; Aedes spp, Culex spp, Anopheles spp, dan Mansonia spp. ${ }^{1}$

Kemampuan nyamuk sebagai vektor yang membawa dan menyebarkan plasmodium sebagai penyebab penyakit malaria dilaporkan terus meningkat dan menyebabkan kematian setiap tahun. Secara global di tahun 2015 malaria menyebabkan 430.000 kematian. ${ }^{2}$ Nyamuk juga merupakan vektor yang menularkan penyakit demam berdarah dengue (Nyamuk Aedes aegypti). Menurut laporan WHO insiden dengue meningkat 30 kali lipat dalam 30 tahun terakhir. Untuk provinsi Sulawesi Utara angka IR yang dilaporkan di tahun 2012 masih cukup tinggi yaitu 55.30 per 100.000 penduduk. Angka kejadian diatas tentunya tidak lepas dari peran nyamuk sebagai vektor., ${ }^{2,3}$

Nyamuk betina membutuhkan protein darah untuk pematangan telurnya, untuk itu nyamuk betina akan mencari hospes untuk menjadi sumber protein darah yang dibutuhkan. Asam amino dan ion dalam darah penting untuk proses oogenesis, maturasi oosit, pembentukan fat body melalui proses previtelogenik, dan vitellogenik. ${ }^{4}$ Kesukaan nyamuk untuk menggigit hospes berbeda-beda, ada yang hanya mengisap darah manusia (antropofilik), mengisap darah binatang (zoofilik) dan yang mengisap keduanya tetapi lebih suka mengisap darah binatang (antropozoofilik). ${ }^{1}$

Nyamuk sebagai vektor yang efektif dan efisien dinilai dengan menggunakan indikator kompetensi vektorial. Salah satu komponen dalam menilai kompetensi vektorial adalah sifat antropofilik nyamuk, yaitu kesukaan nyamuk mengisap darah manusia yang merupakan sifat nyamuk untuk dapat terinfeksi dan menularkan parasit antar manusia. Dalam menilai sifat antropofilik maka diperlukan suatu penilaian pakan darah nyamuk yang berasal dari manusia sehingga dapat memperkirakan kebiasaan nyamuk menggigit manusia. ${ }^{5,6}$ Salah satu uji yang dapat dilakukan dalam penentuan ini adalah dengan menggunakan uji presipitasi.

Salah satu metode yang dapat digunakan dalam mendeteksi darah dari hospes manusias yaitu melalui tes benzidine yang dinilai sangat sensitif dalam mendeteksi adanya porfirin besi (heme) dari hemoglobin. Porfirin besi (heme) dari darah hospes manusia akan tetap ada pada lambung nyamuk setelah protein serum darah dicerna, sehingga memungkinkan untuk dilakukan identifikasi asal pakan darah nyamuk dan menilai sifat antropofilik nyamuk. $^{7}$

Penelitian ini bertujuan untuk mengetahui apakah nyamuk yang mengisap darah hospes manusia (antropofilik) dapat dideteksi dengan uji benzidine di Kota Manado

\section{METODE PENELITIAN}

Desain penelitian yang digunakan dalam penelitian ini yaitu survei deskriptif. Penelitian dilakukan di Lima Kecamatan yang ada di Kota Manado yaitu Kecamatan Malalayang, Kecamatan Wanea, Kecamatan Sario, Kecamatan Tikala, dan Kecamatan Wenang pada bulan September hingga November 2016. Subyek penelitian yaitu nyamuk liar dewasa (wild mosquitoes) yang ditangkap di lokasi penelitian yang memenuhi kriteria inklusi, yaitu nyamuk betina yang ditangkap di dalam dan di luar rumah pada siang hari, sore hari, dan malam hari. Variabel penelitian yaitu spesies nyamuk di daerah penelitian dan uji benzidine pakan darah.

Penangkapan nyamuk dilakukan menggunakan metode umpan manusia dan sweeping pada lokasi dengan aktivitas manusia di jam puncak menggigit, yaitu pada pagi hari (06:00-09:00), sore hari (15:00-18:00), dan malam hari (20:0000:00). Setelah itu dilakukan identifikasi nyamuk dan pengelompokan berdasarkan genus dan dilakukan pemisahan segmen abdomen nyamuk untuk dilakukan pemeriksaan pakan darah semi kuantitatif menggunakan benzidine dan dilanjutkan 
dengan pemeriksaan kualitatif menggunakan mesin reflotron.

\section{HASIL PENELITIAN \\ Hasil penangkapan nyamuk betina}

Hasil penangkapan nyamuk menggunakan umpan manusia disajikan pada Tabel 1 dan nyamuk yang ditangkap menggunakan metode sweeping disajikan pada Tabel 2. Keseluruhan jumlah nyamuk yang tertangkap ialah 158 ekor nyamuk betina yang terdiri dari 101 genus Aedes spp dan 57 genus Culex spp. Selama penelitian dilakukan pengukuran suhu dan kelembaban di lokasi tempat penangkapan nyamuk. Hasil penangkapan nyamuk berdasarkan suhu disajikan pada Tabel 3 dan hasil penangkapan nyamuk berdasarkan kelembaban disajikan pada Tabel 4.

Tabel 1. Jumlah nyamuk betina yang tertangkap dengan umpan manusia berdasarkan genus

\begin{tabular}{cccccc}
\hline \multirow{2}{*}{ Lokasi Penangkapan } & \multirow{2}{*}{ Jam } & \multicolumn{3}{c}{ Genus } \\
\cline { 3 - 6 } & Penangkapan & Aedes $s p p$ & \multicolumn{2}{c}{ Culex spp } \\
\cline { 3 - 6 } & & $\begin{array}{c}\text { Dalam } \\
\text { rumah }\end{array}$ & $\begin{array}{c}\text { Luar } \\
\text { rumah }\end{array}$ & $\begin{array}{c}\text { Dalam } \\
\text { rumah }\end{array}$ & Luar rumah \\
& & 3 & 17 & 0 & 0 \\
Kecamatan Malalayang & $15: 00-18: 00$ & 0 & 5 & 0 & 0 \\
Kecamatan Wanea & $20: 00-00: 00$ & 0 & 1 & 4 & 0 \\
& $06: 00-09: 00$ & 0 & 2 & 0 & 1 \\
Kecamatan Sario & $15: 00-18: 00$ & 4 & 0 & 0 & 0 \\
& $20: 00-00: 00$ & 0 & 2 & 1 & 1 \\
Kecamatan Tikala & $06: 00-09: 00$ & 1 & 2 & 0 & 0 \\
& $15: 00-18: 00$ & 13 & 0 & 0 & 0 \\
Kecamatan Wenang & $20: 00-00: 00$ & 0 & 0 & 1 & 0 \\
& $06: 00-09: 00$ & 2 & 0 & 0 & 0 \\
& $15: 00-18: 00$ & 0 & 0 & 0 & 0 \\
Jumlah & $20: 00-00: 00$ & 0 & 3 & 0 & 1 \\
& $06: 00-09: 00$ & 1 & 0 & 1 & 0 \\
& $15: 00-18: 00$ & 0 & 0 & 0 & 0 \\
& $20: 00-00: 00$ & 0 & 0 & 1 & 21 \\
\hline
\end{tabular}

Tabel 2. Jumlah nyamuk betina yang tertangkap dengan metode sweeping berdasarkan genus

\begin{tabular}{cccccc}
\hline \multirow{2}{*}{ Lokasi Penangkapan } & \multirow{2}{*}{ Jam } & \multicolumn{3}{c}{ Genus } \\
\cline { 3 - 6 } & Penangkapan & \multicolumn{2}{c}{ Aedes spp } & \multicolumn{2}{c}{ Culex spp } \\
\cline { 3 - 6 } & & $\begin{array}{c}\text { Dalam } \\
\text { rumah }\end{array}$ & $\begin{array}{c}\text { Luar } \\
\text { rumah }\end{array}$ & $\begin{array}{c}\text { Dalam } \\
\text { rumah }\end{array}$ & $\begin{array}{c}\text { Luar } \\
\text { rumah }\end{array}$ \\
\hline Kecamatan Malalayang & $06: 00-09: 00$ & 2 & 0 & 0 & 0 \\
& $15: 00-18: 00$ & 25 & 8 & 3 & 0 \\
Kecamatan Wanea & $20: 00-00: 00$ & 1 & 0 & 4 & 0 \\
& $06: 00-09: 00$ & 0 & 0 & 0 & 0 \\
Kecamatan Sario & $15: 00-18: 00$ & 2 & 0 & 1 & 0 \\
& $20: 00-00: 00$ & 0 & 0 & 0 & 3 \\
Kecamatan Tikala & $06: 00-09: 00$ & 0 & 0 & 0 & 0 \\
& $15: 00-18: 00$ & 3 & 2 & 0 & 0 \\
Kecamatan Wenang & $20: 00-00: 00$ & 0 & 0 & 1 & 0 \\
& $06: 00-09: 00$ & 0 & 0 & 0 & 0 \\
& $15: 00-18: 00$ & 0 & 0 & 2 & 0 \\
Jumlah & $20: 00-00: 00$ & 0 & 0 & 0 & 1 \\
& $06: 00-09: 00$ & 0 & 2 & 0 & 0 \\
& $15: 00-18: 00$ & 0 & 0 & 0 & 0 \\
& $20: 00-00: 00$ & 0 & 0 & 0 & 10 \\
& & 33 & 12 & 11 & 14 \\
\hline
\end{tabular}


Tabel 4. Nyamuk betina yang tertangkap berdasarkan suhu

\begin{tabular}{cccc}
\hline \multirow{2}{*}{ Genus } & \multicolumn{3}{c}{ Suhu $\left({ }^{\mathbf{0}} \mathbf{C}\right)$} \\
\cline { 2 - 4 } & $26-27.9$ & $28-29.9$ & $30-32$ \\
\hline Aedes spp & 14 & 59 & 27 \\
Culex spp & 6 & 43 & 9 \\
Total & 20 & 102 & 36 \\
\hline
\end{tabular}

Dari hasil penangkapan ditemukan jumlah nyamuk yang paling banyak tertangkap berada di lokasi dengan suhu $28-29.9^{\circ} \mathrm{c}$ dengan jumlah 102 ekor nyamuk betina sedangkan menurut kelembapan, jumlah nyamuk terbanyak tertangkap pada kelembapan 77-81.9\% dengan jumlah 67 ekor nyamuk betina.

Tabel 5. Nyamuk betina yang tertangkap berdasarkan kelembaban

\begin{tabular}{rcccc}
\hline Genus & \multicolumn{4}{c}{ Kelembaban (\%) } \\
\cline { 2 - 5 } & $67-71.9$ & $72-76.9$ & $77-81.9$ & $82-87$ \\
\hline Aedes spp & 3 & 35 & 50 & 22 \\
Culex spp & 0 & 21 & 17 & 10 \\
Total & 3 & 56 & 67 & 32 \\
\hline
\end{tabular}

\section{Identifikasi pakan darah semi kuantitatif menggunakan pemeriksaan benzidine.}

Hasil pemeriksaan pakan darah semi kuantitatif menggunakan benzidine disajikan dalam Tabel 6. Dari 158 nyamuk betina yang diperiksa, terdapat 155 ekor nyamuk yang mengalami perubahan warna pada indikator yang bervariasi dari 1+ hingga $5+$ dan 3 ekor nyamuk yang tidak mengalami perubahan warna pada indikator. Dari hasil pemeriksaan pakan darah ditemukan sebagian besar nyamuk betina yang diperiksa menunjukan perubahan warna dengan indikator 4+ sedangkan yang paling sedikit menunjukan perubahan warna dengan indikator $1+$.

\section{Identifikasi pakan darah kualitatif}

Setelah dilakukan pemeriksaan menggunakan benzidine test, beberapa sampel nyamuk yang diperiksa sebelumnya dilanjutkan dengan pemeriksaan pakan darah kualitatif menggunakan mesin reflotron. Data pemeriksaan ini disajikan pada Tabel 7. Dari Tabel 7 dapat dilihat bahwa pembacaan yang paling banyak ditunjukan adalah hasil dengan indikator 5+ diikuti berturut-turut $3+$ dan $2+$. Sedangkan untuk hasil 4+ yang sebelumnya paling banyak banyak terbaca pada pemeriksaan benzidine test tidak ditunjukan pada pemeriksaan ini.

Tabel 6. Hasil pemeriksaan semi kuantitatif pakan darah nyamuk

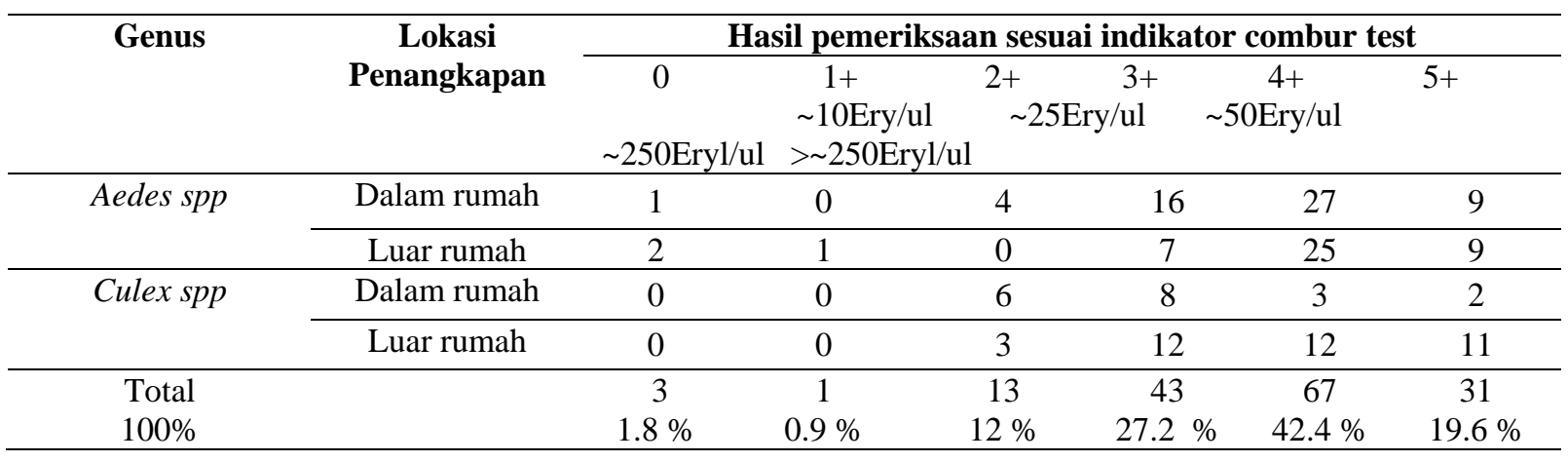

Tabel 7. Hasil pemeriksaan kualitatif pakan darah nyamuk

\begin{tabular}{ccccccc}
\hline Genus & \multicolumn{7}{c}{ Hasil pemeriksaan Reflotron } \\
\cline { 2 - 7 } & 0 & $1+$ & $2+$ & $3+$ & $4+$ & $5+$ \\
\hline Aedes spp & 0 & 0 & 1 & 2 & 0 & 3 \\
Culex spp & 0 & 0 & 0 & 0 & 0 & 3 \\
Total & 0 & 0 & 1 & 2 & 0 & 6 \\
$100 \%$ & $0 \%$ & $0 \%$ & $11 \%$ & $22 \%$ & $0 \%$ & $66 \%$ \\
\hline
\end{tabular}




\section{BAHASAN}

Jumlah nyamuk betina yang tertangkap dalam penelitian ini berjumlah 158 ekor, dimana jumlah nyamuk ini tergolong sedikit yang kemungkinan diakibatkan karena faktor bionomik pada waktu penangkapan. Penangkapan nyamuk di lokasi penelitian ditemukan 2 jenis nyamuk yaitu Aedes spp dan Culex spp dengan jumlah terbanyak yaitu Aedes spp. Banyaknya nyamuk Aedes spp dan Culex spp yang ditemukan menunjukan bahwa kedua nyamuk ini yang paling banyak bersifat antropofilik di Kota Manado. Sifat antropofilik merupakan hal yang mutlak bagi nyamuk untuk dapat menularkan parasit antar manusia, sehingga penyakitpenyakit yang dapat ditularkan oleh nyamuk ini perlu menjadi perhatian di Kota Manado. Hasil ini dapat kita lihat dari kejadian kasus demam berdarah dengue yang ditularkan oleh Aedes spp yang paling banyak ditemukan dalam penelitian ini.

Pongsilurang dkk (2015) melaporkan bahwa kejadian demam berdarah terjadi di semua Kecamatan yang ada di Kota Manado, dengan kasus tertinggi yang dilaporkan oleh Mangaku dkk (2013) terjadi di Kecamatan Malalayang, di ikuti berturut-turut Kecamatan Tikala, Wanea, Mapanget, Sario, Tuminting, Singkil, dan Bunaken. ${ }^{8,9}$

Berdasarkan suhu yang diukur pada lokasi penangkapan, ditemukan dengan hasil terbanyak pada suhu yang berkisar antara $28-29.9{ }^{\circ} \mathrm{C}$ disusul $30-32^{\circ} \mathrm{C}$. Hal ini disebabkan karena nyamuk memiliki suhu optimal dalam perkembangbiakannya yaitu berkisar $28-33^{\circ} \mathrm{C}$ yang hampir sama untuk semua populasi. ${ }^{10}$ Suhu optimal nyamuk diketahui telah mengalami perubahan dari yang dulunya dilaporkan berkisar antara $20-25^{\circ} \mathrm{C}^{11}$ Suhu tropis ini akan mendorong perkembangbiakan nyamuk dimana nyamuk akan mengoptimalkan durasi siklus gonotropiknya. ${ }^{12}$ Selain itu berdasarkan kelembaban ditemukan variasi kelembapan pada lokasi penangkapan nyamuk yaitu antara 67-87\%. Hal ini dihubungkan dengan kepadatan nyamuk yang akan meningkat pada kelembaban relatif diatas $60 \%$ karena kelembaban yang lebih tinggi akan mendukung nyamuk mempertahankan kehidupannya. ${ }^{11}$

Adanya perubahan warna pada indikator mengindikasikan adanya porfirin besi (heme) pada nyamuk yang disebabkan oleh reaksi oksidasi chromogen (benzidine). Pemeriksaan benzidine tidak spesifik, tapi pemeriksaan ini sangat sensitif pada deteksi porfirin besi. O'Gower (1955) melaporkan bahwa porfirin besi akan tetap ada pada abdomen nyamuk bahkan setelah protein serum dicerna sehingga memungkinkan untuk dilakukan pemeriksaan heme. ${ }^{7}$ Bertahannya heme pada sistem pencernaan nyamuk dikaitkan dengan hasil penelitian Devenport dkk (2006) tentang mekanisme nyamuk untuk mencegah stress oksidatif iron-mediated dari pakan darah dengan suatu protein pengikat hemoglobin yang dihasilkan oleh perithropic matrix (PM) pada midgut nyamuk. ${ }^{13}$ Hal ini juga didukung oleh Zhou dkk (2007) yang melaporkan bahwa bentuk besi yang terekskresi pada akhir pencernaan pakan darah nyamuk adalah heme, ${ }^{14}$ yang juga dibuktikan dengan pemeriksaan benzidine pada hasil defekasi nyamuk yang positif mengandung heme oleh O'Gower (1955). ${ }^{\text {? }}$

Jumlah heme yang dideteksi bervariasi sesuai indikator pada indikator benzidine. Intensitas perubahan warna yang beragam pada penelitian ini terjadi sebanding dengan jumlah porfirin besi pada nyamuk. Hal ini menunjukkan adanya perbedaan kandungan porfirin besi dan variasi volume pakan darah pada masing-masing sampel nyamuk betina yang diperiksa. Perbedaan jumlah porfirin besi dapat dihubungkan dengan perilaku makan pakan darah antar nyamuk yang dipengaruhi oleh tingkat pencernaan nyamuk, durasi makan pakan darah, dan tingkat pengambilan pakan darah. ${ }^{15}$ Pada penelitian Chadee dkk (2002) dilaporkan tingkat pengambilan pakan darah ditentukan oleh distribusi pembuluh darah pada host dimana perbedaan pada vaskularisasi kulit manusia mempengaruhi kemungkinan nyamuk akan menghisap darah pada kapiler. ${ }^{16,17}$ Selain itu 
dilaporkan juga oleh Banerjee dkk (1991) bahwa perbedaan perilaku nyamuk menghisap darah juga berhubungan erat dengan kondisi lingkungan setempat. ${ }^{18}$

Pada penelitian ini ditemukan 7 ekor nyamuk Aedes spp yang menggigit pada malam hari (20:00-00:00) yang ditemui di 3 kecamatan yaitu Kecamatan Malalayang, Kecamatan Wenang, dan Kecamatan Wanea. Temuan ini menunjukan adanya perilaku nokturnal Aedes spp dimana sejauh ini diketahui aktif menghisap darah pada siang hari (diurnal). Temuan ini juga didukung oleh Hadi dkk (2012) yang melaporkan bahwa kedua jenis vektor demam berdarah yaitu Ae. aegypti dan Ae. albopictus tidak hanya aktif mengisap darah pada siang hari tetapi juga pada malam hari. ${ }^{19}$

\section{SIMPULAN}

Berdasarkan hasil penelitian, dapat disimpulkan bahwa uji benzidine dapat dilakukan untuk penilaian pakan darah nyamuk dalam menentukan sifat antropofilik nyamuk.

\section{SARAN}

Bagi penelitian selanjutnya disarankan untuk melakukan perbandingan uji benzidine dengan metode yang lain

Disarankan untuk melakukan penelitian pada spesies nyamuk yang lain serta melakukan penelitian yang berhubungan dengan aspek bionomik nyamuk

\section{DAFTAR PUSTAKA}

1. Staf pengajar Departemen Parasitologi FKUI. Parasitologi Kedokteran. Edisi ke-4. Jakarta: Balai Penerbit FKUI; 2011.

2. World Health Organization. Mosquito-borne disease. 2016 [cited 2016 Sept 4]. Available from: http://www.who.int/neglected_diseas es/vector_ecology/mosquito-bornediseases/en/

3. Pusat data dan informasi Kementrian Kesehatan Republik Indonesia. Peta Kesehatan Nasional 2012. 2013 [cited 2016 Sept 4]. Available from: http://www.pusdatin.kemkes.go.id/do wnload.php?file=download/pusdatin/ peta-kesehatan/peta-kesehatan-

2012.pdf

4. Lusiyana N. Cahyani MST. Kolonisasi nyamuk Aedes aegypti menggunakan teknik membran artifisial di laboratorium. JKKI. 2014; 6: 120-27.

5. Widyastuti U. Inkriminasi vektor malaria dan identifikasi pakan darah pada nyamuk anopheles spp di Kecamatan Borobudur, Kabupaten Malang. Vektora. 2013; 1:18-27.

6. Widyastuti U, Boewono DT, Widiarti, Supargiyono, Satoto TBT. Kompetensi vektorial anopheles maculates theobald di Kecamatan Kokap, Kabupaten Kulonprogo. Media Litbangkes; 23:47-57.

7. O'Gower. The Rate of Digestion of, Human Blood by Certain Species of Mosquitoes. Australian Journal of Biological Sciences. 1956; 9(1): 12529.

8. Pongsilurang CM, Sapulete MR, Kaunang WPJ. Pemetaan kasus demam berdarah dengue di Kota Manado. Jurnal kedokteran komunitas dan tropik. 2015; 2: 66-72.

9. Mangaku MC, Sondakh RC, Loho H. Hubungan antara pengetahuan masyarakat dengan tindakan pencegahan demam berdarah dengue di kelurahan bumi nyiur kecamatan wanea Kota Manado. 2013 [cited 5 Desember 2016]. Available from: http://fkm.unsrat.ac.id/wpcontent/uploads/2013/11/jurnal1.pdf.

10. Dickerson CZ. The effects of temperature and humidity on the eggs of Aedes aegypti and Aedes albopictus in texas [disertasi]. [Texas]: Texas A\&M University; 2007.

11. Yasuko J, Levins R. Ecology of vector mosquitoes in srilanka-suggestions for future mosquitoe control in rise ecosystems. Southeast Asian J Trop Med Public Health. 2007; 38(4): 64657.

12. Okogun GRA, Anosike JC, Okere AN, Nwoke BEB. Ecology of mosquitoes of Midwestern Nigeria. J Vect Borne Dis 42. 2005: 1-8.

13. Devenport $M$, Alvarenga $\mathbf{P H}$, Shao L, Fujioka H, Bianconi ML, Oliveira PL, et al. Identification of Aedes 
aegypti peritrophic matrix protein AeIMUCI as heme-binding protein. Biochemistry. 2006; 45: 9540-49.

14. Zhou G, Kohlhepp P, Geiser D, Frasquillo MDC, Moreno LV, Winzerling JJ. Fate of blood meal iron in mosquitos. J Insect Physiol. 2007; 53(11): 1169-1178.

15. Ribeiro JMC, Rossignol PA, Spielman A. Aedes aegypti: model for blood finding behavior and prediction of parasite manipulation. Experimental Parasitology. 1985; 60: 118-132.

16. Chadee DD, Beier JC, Mohammed RT. Fast and slow blood-feeding durations of Aedes aegypti mosquitoes in Trinidad. Journal of
Vector Ekology. 2002; 172-77.

17. MacDougal C. Effects of blood meal size on mosquito response to disturbance while blood feeding on a simulated host [thesis]. [Columbia]: University of Victoria; 2005.

18. Banerjee, PK., KN. Ghosh and RN. Gel diffusion analysis of host reference pattern of An. subpictus in West Bengal, India. Indian J. Malariol. 1991; 28: 157-159.

19. Hadi UK, Soviana S, Gunandini DD. Aktivitas nokturnal vektor demam berdarah dengue di beberapa daerah di Indonesia. Jurnal entomogi Indonesia. 2012; 9: 1-6. 